\title{
The Brand Potential of "Soft" Factors of the Territorial Capital: A Study of Eight Medium- Sized Cities in Serbia ${ }^{1}$
}

\author{
Milena Toković \\ University of Belgrade, Faculty of Philosophy, Serbia \\ e-mail:mstanojevic85@gmail.com
}

\author{
Mina Petrović \\ University of Belgrade, Faculty of Philosophy, Serbia \\ e-mail: mipetrov@f.bg.ac.rs
}

\begin{abstract}
The aim of this paper was to explore the brand potential of certain "soft" factors of territorial capital in the medium-sized cities in Serbia. The concept of territorial capital refers to the total city development potential that combines objective, "hard" and subjective, "soft" factors of an area, in order to attract investment and generate local development. As city branding has become an imperative of local development strategies, this paper aims at connecting these concepts in order to emphasize a possible brand potential of some "soft" dimensions of territorial capital. The paper is based on the data obtained from the research conducted from 2013 to 2015 by the Institute for Sociological Research of University of Belgrade on a representative sample of population aged 18-65 in eight medium-sized cities in Serbia. The first part of the paper presents the concept of territorial capital and clarifies its connection with the city branding. The second part of the paper is dedicated to the analysis related to Serbia. It begins by summarizing the key features of its socio-spatial transformation in the post-socialist period and points to the discordance between the state of territorial capital and the city branding process. Then the method of research which focuses on the citizens' perception (a neglected soft dimension of territorial capital) is presented. The obtained questionnaire results are analysed through the lens of the city branding approach and the application of somewhat modified dimensions (presence, pulse and people) of the City Brand Index (CBI). The concluding part briefly recaps how and why the observed soft dimensions of the territorial capital might be recognized as a relevant potential in the process of (re) branding of the researched cities.
\end{abstract}

Key words: city branding, territorial capital, "soft" factors of the territorial capital, Serbia.

$\mathbf{1}$ This paper results from the work on the project Challenges of the new social integration in Serbia - concepts and actors (ev. No 179035), funded by the Ministry of Education, Science and Technological Development of the Republic of Serbia. 


\section{Introduction}

The aim of the paper is to link the concept of territorial capital with city branding considered as an integral part of local development strategies based on endogenous resources (Kavaratzis and Ashworth, 2010; Anholt, 2007; Petrović, 2009; Petrović and Toković, 2016). As such, city branding could not be taken only as a marketing concept, but as a concept which relates to long-term socio-economic processes (Anholt, 2007.). The concept of territorial capital, initially developed by institutional economy but well adopted by different disciplines within the field of urban studies, found its place in urban sociology as the concept suitable for approaching towns like a coherent wholes, as social communities (Petrović, 2014a:86). Even though branding has to be considered from interdisciplinary perspective, this paper is not based on interdisciplinary approach but is intended primarily to illustrate that sociology has its place in the city branding process in the sense of both academic and policy approach. The analysis is based on empirical research conducted in eight less developed mediumsized towns in Serbia, considered as good examples of cities facing challenges in activating local resources. By focusing on residents' perception of their cities, taken as a specific soft dimension of a territorial capital, we argue that these data should be seen as specific potential for city branding. The argument is based on the presumption that city branding should start from the existing reality in making efforts to improve it, as being an integral part of strategic city development (Anholt, 2007:4, 2010:5). Thus, we claim that citizens' perception, which is completely neglected, contains some positive aspects of the otherwise unfavorable features of the observed cities' territorial capital in Serbia. Therefore, the presented analysis might be of interest not only for scholars but also for various stakeholders in the process of city (re)branding.

\section{Linking the concepts: territorial capital and city branding}

With the neoliberal approach to territorial development policy, the cities' locally specific resources have been brought into the focus of urban policy, and the concept of territorial capital has become frequently used since it 'mirrors' the concept of competitiveness between the cities in attracting different forms of capital (human, financial, etc.) (Petrović, 2014:49). According to the OECD definition (2001), territorial capital represents "a special set of factors of a given area which attracts investments, i.e. which makes the investments in a given area more profitable, and the yields on investments higher than in other areas (in fact, not in the case of all the investments, but of those that provide the highest yield in the specified area), therefore it is more advisable to invest in this particular area than elsewhere" (Vujošević, Zeković i Maričić, 2010:40). The EU development policies encourage the strengthening of sub-national levels and the identities of territorial units as well as the strategic approach to their local potentials, i.e. their territorial capital (Petrović, 2014:72; Brighetti, 2010; Vujošević et al. 2010:5, 107, 205).

In an attempt to "decompose" territorial capital and give an answer to the question about what it consists of, there are mainly two groups of dimensions: "hard" and "soft" ones. Storper (1997) includes a city's geostrategic position, climate, size, natu- 
ral resources, economic structure of infrastructure, labor, technology, environment, monumental heritage and cultural legacy, "human capital", quality of life, quality of the environment, technical infrastructure development into the "hard" dimensions (the so-called "objective factors"). The "soft" dimensions, also called "subjective", represent cognitive, cultural and institutional capital of an area. These dimensions include understanding of processes and phenomena, information, relation-specific skills and knowledge, conventions, common strategies and practical policies, innovation capacity, the amounts of transaction costs, social capital, strategic reasoning development, development of communication networks and networks for interaction between various actors, subjective elements such as regional and local customs and tradition, regional mentality of the population and its particularities, etc. (Storper, 1997:20; Vujošević et al, 2010:41; Stanojević, 2014:186; Petrović, 2014a:14).

Analytical attention has been directed towards the soft dimensions of territorial capital in so far as they represent the activation of "hard"resources. The latter are included in traditional supply factors, whereas the "soft" dimensions belong to the sphere of potential, since they are not necessarily linked to the economic goals directly (Camagni and Capello, 2008). Therefore, this classification should be solely considered as ideal-typical, because there are some elements of territorial capital that have the characteristics of both groups of the factors.

A city's physical features are quite important for conversion of local resources into territorial capital, but social structures and relations, i.e. the actors' capacity to use the resources in a way which creates the value of common interest or in which the local social structure contributes to the city's economic development are essential (Camagni and Cappelo, 2008). Thus, local (economic) development has also been considered a strategic project of a local community (Cox, 1997). A strong internal culture is what builds a city's good reputation and directly affects its economic, political, social and cultural development (Anholt, 2007).

The territorial capital enhancing has also been directly linked to city branding strategy. Namely, the elements of territorial capital represent the basis of a city's branding development strategy, and they have become a significant precondition of successful competition in the field of image - symbolic value. As for the process of (re)branding it is necessary to consider a territory's structural elements (territorial capital), but the identification of non-activated local resources (territorial potential) is even more important (Stanojević, 2014:188). The importance the soft dimensions of territorial capital for a possible positive effect of the total territorial capital of an area as well as a possibility of its rebranding has been confirmed by the European documents related to economic development (Devetaković, 2012:32-33). A managerial approach to city (re)branding primarily emphasizes innovation, which links its success to the potentials associated with the soft dimensions of territorial capital.

City rebranding is often faced with contradictory requirements: a city should emphasize or preserve its authenticity, but also provide a standardized experience of the urban milieu which often means a commodification of urban space and local culture, thus diminishing their authenticity (Zukin, 1996:237; Ritzer, 2001; Jayne, 2006:121; 
Petrović, 2009:92-93). Therefore, a critical approach to branding also discusses an issue of "invented traditions" (Hobbsbawm and Ranger, 1983), i.e. a phenomenon of a city's image presentations being increasingly separated from reality (Anholt, 2007). The critics also refer to the fact that city (re)branding implies a decontextualization of traditional culture as well as removing all potentially negative elements of the iconography of a city (crime, ugly architecture, unemployment, etc.), while the city's historical legacy and the re-creation of historical narrative have been economically valorized through tourism (Horlings, 2012; Storper, 1997; Petrović, 2014:72; Petrović, 2009:90, 92, 96; Zukin, 1995; Miles and Miles, 2004:5; Anholt, 2007).

It is these critical remarks that suggest to be cautious in linking the concept of territorial capital to a city's image. Namely, although the concept of territorial capital is dynamic, since it implies that local actors strategically examine structural predispositions of their acting within a city's framework, the city's image cannot be changed quickly. This is due to the strong beliefs, i.e. impressions that social actors have about a particular city (Anholt, 2007). These beliefs cannot be easily changed only by marketing strategies (a city's new logo and slogan), and in this sense the city brand, i.e. the city reputation as an important brand dimension, cannot be constructed, but it may only be deserved. This means that a change in the actors' behavior, i.e. the actual conditions/quality of life is what can affect a different perception of the city (Anholt, 2007; Anholt, 2010). According to the Anholt: "but there appears to be no evidence to suggest that using marketing communications to influence international public perceptions of an entire city, region or country is anything other than a vain and foolish waste of taxpayers' money" (2008:1).

Keith Dinnie (2011) states that city branding is a topic of significant interest to both academics and policy makers. While the concept of city branding is often identified with the marketing activities to promote the cities and to address the target groups on the market, scientific sub-disciplines such as urban and regional economics, economic geography, cultural studies and social geography significantly have contributed to broader understanding of city branding (Luković, 2013:21).

Urban policy researchers advocated in particular two approaches: historical, which sees the promotion of cities as a part of a broader process of economic and social change; and critical, which emphasizes that cities are not typical products and opposes to marketing techniques, since they neglect cultural and social characteristics of cities (Hankinson, 2010:8). The historical approach is quite close to the sociological perspective which we want to link with Anholt's interpretation of place branding, as we believe it acknowledges the importance of achieving broader economic, social and cultural benefits within the process of branding, and insists on the conceptual separation of branding places and branded products. Anholt describes place branding as a powerful instrument for the implementation of broad social and cultural changes (Anholt, 2005:140). Therefore, it is indisputable that the concept of place branding involves a wider social perspective and specific developmental relevance that cannot be placed under the umbrella of technique of strategic planning and the application of social marketing (Luković, 2013). 
Anholt has even substituted the term brand by the notion of competitive identity in order to further emphasize that branding is not exclusively related to marketing communication. He believes that cities are assessed according to the way they function, not the way they communicate, a city's reputation may not be built nor changed by the means of communication (design/advertising), but by the means of major changes in political and social fabric of the modern society (Anholt, 2015:40, 43). In one of the rare sociological books dedicated to brands, Celia Lury emphasized exactly the same point by suggesting that it was a sociological imperative to consider brands as a platform for activity patterning, as an open object extending or implicating social relations, and as an object of possibility (2004:1-14). By accepting such sociological interpretation of brands in general, we found Anholt's approach suitable for observing the city brand potentials through soft dimensions of territorial capital. Within the scope of this paper we constrained the analysis on the city residents' perception and opinions that are recognized as significant input in city branding by both academic and policy literature that acknowledges broader meaning of this notion (Kavaratzis and Ashwort, 2010; Houghton and Stevens, 2011; Anholt, 2007; 2010; Ashwort, Kavaratzis and Warnaby, 2015; Švob - Đokić, 2007; Kotler et al, 1999). Therefore, the residents' attitudes are taken as a specific cognitive (soft) dimension of territorial capital that we analyze by analogy with certain dimensions of Anholt's City Brand Index.

\section{Territorial capital and city branding potential in Serbia: empirical research findings}

Before we turn to a more detailed presentation of applied methodology and data analysis we will concisely describe the context of Serbian society having in mind the link between the quality of territorial capital and the city branding process.

The events in recent history (the breakup of Yugoslavia, disappearance of the former common market, international sanctions and isolation of the country, etc.) have influenced the unfavorable development of Serbia and its territorial capital. Serbia went through the periods of a long-lasting economic stagnation and very complex processes of re/territorialization (Petrović, 2014:72), with huge concentration of development potentials in few cities (Devetaković, 2012:32-33; Molnar, 2013:68). Apart from Belgrade and Novi Sad, metropolitan areas that occupy about $7 \%$ of the total territory of Serbia, but with $27,1 \%$ of the population, $41,6 \%$ of the employees and $45,6 \%$ of the national income, other cities are stagnating, while some (mono)industrial cities and rural areas are facing almost complete collapse (Vujošević et al. 2010; Vujošević, 2014).

As in most post-socialist countries, the change of the dominant political culture and the prevailing value patterns (Cvejić, 2010), primarily the acceptance of individualistic-liberal norms with market relations and retention of collectively-redistributive values (Lazić, 2011), were crucial for stabilization of the new social order in Serbia. Both pre-socialist and socialist legacy are considered inadequate for a rapid and successful institutional transformation towards a capitalist city. Urban transition stimu- 
lates the market development, commercialization of the cities' historical cores, and a growth of socio-spatial segregation while diminishing the importance of urban planning (Petovar, 2003; Vujović, 2014; Petrović, 2009; Backović, 2005). These problems are hard to tackle due to the significant weakness of soft dimensions of territorial capital. Namely, there is a lack of "planning culture" and strategic management that indicates the "institutional sclerosis", i.e. the institutions resistant to changes. The strategies are not adopted thanks to their importance for the initiation of development, but only as a condition for the assets withdrawal from either national or foreign funds. The participative approach was largely neglected, particularly regarding the inclusion of citizens and respecting their opinions and attitudes. A lack of autonomy and competence of city administration may be observed as legacy of redistributive development concept based on the top-down transfers, which is still preferable. As such it has been a considerable obstacle to the implementation of development strategies based on local resources and the city branding process as its integral part (Lazarević-Bajec, 2009; Vujošević et al, 2010; Vujošević, 2014; Petrović, 2009; Petrović, 2014).

\subsection{Methods employed in the analysis}

The way residents perceive their cities as a specific (cognitive) soft dimension of territorial capital is completely neglected in Serbia. Following the Anholt's statement that city branding involves the beliefs or impressions that social actors have about a particular city, and the fact that city residents are among the important actors (stakeholders) in the city branding process who actually build the city brands (Ashworth et al., 2015:5-6), we focused our analysis on the residents' perception about their cities. The analysis is based on the empirical survey findings obtained through questionnaire technique within the project "Territorial capital in Serbia: structural and operational potential of local development", which was conducted by the Institute for Sociological Research in three stages between 2013 and 2015, in eight medium-sized cities (80-120 000 inhabitants). That type of cities was chosen since both the academic community and policy makers show a great interest in small and medium-sized cities and consider the concept of territorial capital as of particular importance for stimulating their endogenous development (Devetaković, 2012:36; Petrović, 2014:57-58). The exact cities were chosen for having a status of functional urban areas of national interest. In each city, the sample of residents was representative regarding the basic socio-demographic characteristics: sex, age and education. The surveyed cities are the following: Kragujevac (N=379), Šabac $(\mathrm{N}=346)$, Užice $(\mathrm{N}=322)$, Novi Pazar $(\mathrm{N}=299)$, Sombor $(\mathrm{N}=288)$, Zrenjanin $(\mathrm{N}=304)$, Leskovac $(\mathrm{N}=301)$, Zaječar $(\mathrm{N}=313)$.

The questionnaire was developed to cover residents' opinion concerning various aspects of the territorial capital. For the purpose of this paper, we focused only on the following: residents' opinions on what makes their city recognizable; the symbols of their city or characteristics of which the city residents are well-known; a specific atmosphere of their city. We argue that results have specific potential for city branding because they reflect the existing reality in the examined cities, which 
might be taken as a starting point in their city branding. We presume that residents' views contain neglected positive aspects of the otherwise unfavorable features of the observed cities' territorial capital. In order to read the obtained questionnaire results from city branding perspective we employed certain dimensions of Anholt's City Brand Index (CBI).

We used Anholt's technique by method of analogy regarding the meaning of questions employed, as we did not use the identical questions. Namely, we found that certain questions we developed to measure soft dimensions of territorial capital cover the meanings of three CBI's dimensions: presence, pulse and people. The whole CBI has six dimensions (as illustrated in Figure 1, for more details see Anholt 2007; Vasiljević, 2009) which reflect both dimensions of the territorial capital, 'soft' and 'hard' (as points of a hexagon). We will briefly explain just the three chosen and indicate the corresponding questions from our questionnaire.

Figure 1

The City Brands Index hexagon

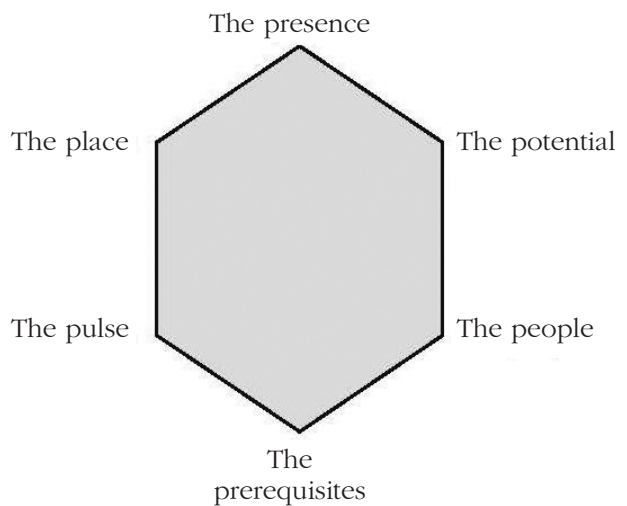

Resource: Anholt, 2007: 60

Presence means a city's standing and status within (inter)national environment, attendance, contribution to science, culture and familiarity/knowledge of a particular city. The corresponding questions are the following: "According to you, what makes your city recognizable?"; „Are there any symbols of your city?"; „Is there any product that makes your city recognizable?"; „Is there any product by which your city used to be recognizable, but it is not any longer?"

Pulse is an important component of a city's image, and it is especially significant for branding process, since it represents an irrational element suitable for creating the city's added value. It corresponds to the presence of lively urban lifestyle or its absence, i.e. the perception of how much people are delighted with the city. It refers to the excitement that is short-term for the visitors and long-term for the residents. The corresponding question is the statement: "The city possesses an atmosphere - the soul which makes it especially appealing", evaluated by resident on the fivepoint Likert scale. 
The last dimension relates to people, the inhabitants, i.e. "software" of a city, their language, culture, openness and kindness of a local population, hospitality, friendliness on the one hand or prejudices and negative attitude on the other. This component also includes the aspect of a city's safety. In our research the people dimension is covered by the question: „Are there any traits which the residents of this city are known for?"

We are turning to the discussion of the results through the lens of the chosen CBI's dimensions now. The results are presented by descriptive statistics, which we found suitable for the employed comparison with the CBI dimensions.

\subsection{Results obtained according to the CBI's dimensions}

\section{Presence}

Table 1 shows up to three most frequent answers ${ }^{2}$ to the question „According to you, what makes your city recognizable?", for each of the examined cities.

Table 1

Features by which a city is recognizable

\begin{tabular}{|l|l|}
\hline & FEATURES BY WHICH A CITY IS RECOGNIZABLE \\
\hline ŠABAC & $\begin{array}{l}\text { Events and festivals (43.8\%) } \\
\text { Historic-cultural monuments/cultural/educational institutions and associations } \\
(22.1 \%),\end{array}$ \\
\hline SOMBOR & $\begin{array}{l}\text { Beauties of nature (53\%) } \\
\text { Historic-cultural monuments/cultural/educational institutions and associations } \\
(18.8 \%)\end{array}$ \\
\hline ZRENJANIN & $\begin{array}{l}\text { Adverse phenomena (20.6\%) } \\
\text { Celebrities (14.6\%) } \\
\text { Events and festivals (10.6\%) }\end{array}$ \\
\hline UŽICE & $\begin{array}{l}\text { Historic-cultural monuments/cultural/educational institutions and associations } \\
(31.5 \%) \\
\text { Traditional food and beverage (28\%) } \\
\text { Factories and industrial products (12.6\%) }\end{array}$ \\
\hline KRAGUJEVAC & $\begin{array}{l}\text { Historic-cultural monuments/cultural/educational institutions and associations } \\
(44.7 \%)\end{array}$ \\
$\begin{array}{l}\text { Factories and industrial products (32.9\%) } \\
\text { Activity typical of the city (15\%) }\end{array}$ \\
\hline NOVI PAZAR & $\begin{array}{l}\text { Historic-cultural monuments/cultural/educational institutions and associations } \\
\text { (23.4\%) } \\
\text { Factories and industrial products (19.5\%) } \\
\text { Traditional food and beverage (16.3\%) }\end{array}$ \\
\hline ZAJEČAR & $\begin{array}{l}\text { Events and festivals (34.2\%) } \\
\text { Historic-cultural monuments/cultural/educational institutions and associations } \\
(22.4 \%) \\
\text { Traditional food and beverage (10.9\%) }\end{array}$ \\
Traditional food and beverage (59\%)
\end{tabular}

$\mathbf{2}$ The answers given by more than $10 \%$ of respondents. 
Based on these results, the cities of Šabac (43.8\%) and Zaječar (34.2\%) are recognized by the respondents as festival cities, Sombor is mostly recognized as a city of nature beauties (53\%), Užice and Novi Pazar are mainly recognized by historic/ cultural monuments and cultural institutions, whereas in Leskovac traditional food has been singled out as its main feature (Leskovac barbecue - kebab). That type of food (mantije - a sort of meat pie) is also recognized as local specificity in Novi Pazar, but in a significantly lower percentage, as the city was also recognized for historic/cultural monuments and industrial products. Zrenjanin is seen as the biggest transformation loser, since a negative image of the city dominates (poor economic conditions, unemployment). From the aspect of city (re)branding, this finding is disturbing, since the city's negative image is particularly resistant to changes. The data about other cities are more optimistic, since all the aforementioned features (festival nature, natural resources, cultural/historical heritage, and gastronomy) indicate that significant group of respondents recognizes other than industrial attributes as being important for the "presence" of the their city, which points that the cities could move away from the image of industrial cities to the cities of consumption, culture and tourism. ${ }^{3}$

Table 2 gives the most frequent answers to the question „Are there any symbols of your city?", including a percentage of the respondents who did not recognize any symbol at all, since we considered it relevant as a good indication of an underprofiled city image, which appeared to be the most frequent answer in five of the observed cities (Zrenjanin, Užice, Kragujevac, Novi Pazar and Leskovac).

Table 2

City symbols

\begin{tabular}{|c|c|}
\hline CITY & CITY SYMBOLS \\
\hline ŠABAC & None/I cannot tell (23.4\%), Historic monuments (23.3\%), Dowel pin (21.1\%), \\
\hline SOMBOR & Coat of arms (25.4\%), None / I cannot tell (25\%), Fiacre (13.4\%) \\
\hline ZRENJANIN & None / I cannot tell (31\%), Four fat horses (22.3\%), Historic monuments (19.7) \\
\hline UŽICE & None / I cannot tell (45.6\%), Historic monuments (25.2\%), Coat of arms (13.8\%) \\
\hline KRAGUJEVAC & None / I cannot tell (31.4\%), Šumarice memorial park (28.5\%), Cross (17.7\%) \\
\hline NOVI PAZAR & $\begin{array}{l}\text { None / I cannot tell (31.2\%), Historic monuments (23.5\%). Altun-alem Mosque } \\
(19.1 \%)\end{array}$ \\
\hline ZAJEČAR & None / I cannot tell (27.6\%), Coat of arms (33.3\%) \\
\hline LESKOVAC & $\begin{array}{l}\text { None / I cannot tell }(55.5 \%) \text {, Traditional food and beverage (20.4\%), Flag and coat of } \\
\text { arms }(12.7 \%)\end{array}$ \\
\hline
\end{tabular}

3 However, further product analysis will show that the residues of industrial heritage are still present. 
The respondents in Leskovac have the least profiled perception of what symbolize their city (55.5\% stated that there are no symbols of the city, i.e. they could not tell). That might be related to the fact that respondents predominantly saw Leskovac as a city recognizable by traditional food that is difficult to code as a symbol. ${ }^{4}$ The respondents saw the symbols of their cities most frequently in historic monuments (Kragujevac 28.5\%, Užice 25.2\%, Novi Pazar 23.5\%, Šabac 23.3\%, Zrenjanin 19.7\%), while just in two cities the official emblems of the cities - the coat of arms and the flag were indicated as city symbols (Zaječar 33.3\%, Sombor 25.4\%). In terms of city (re)branding, the historic monuments recognized as city symbols play an important role from the aspect of a tradition (re)valorization. These results provide us an insight into how the residents recognize the cities' significant history through visual symbols, keeping their memories of certain events from the past alive and thus reproducing a particular image of the city. Thus, we found that, in Kragujevac, the memorial park from the Second World War (Šumarice) is dominant in relation to the city's new religious symbols (Cross), in Užice, the socialist heritage is embedded in the residents' cognitive maps, in Šabac respondents disclosed the pride of their city for being a forerunner in Serbian modernization (by emphasizing the first piano in Serbia, for example) ${ }^{5}$ whereas, in Novi Pazar, respondents pointed to multiculturalism by emphasizing churches and mosques as a city symbols. Besides the (re)valorization of tradition, the symbols specific to certain cities were revealed, which, in the period of globalization, could indicate to a special local potential: Šabac (Dowel pin - 21.1\%) ${ }^{6}$, Zrenjanin (Four Fat Horses mural - 22.3\%), Sombor (Fiacre - 13.4\%).

The next question related to the CBI's dimension of presence is about the product the respondents considered as being typical of the city, both currently and in the past. By this we wanted to examine the cognitive frameworks set by the residents in terms of continuity, i.e. discontinuity of certain development potentials of their cities. This is particularly important to the post-socialist cities which have undergone significant and, compared to other parts of the developed world, delayed changes in respect of the transformation from industrial or Fordist to post/industrial or postFordist model of capitalism. The time continuum contained in the question enables specifying the cities' advantages in the past as well as their (in)capacity to reactivate the process of cities' (re)branding. If we compare the products that respondents named as their city was/is recognizable for in the past/present (Table 3 and Table 4) a shift from the products related to large industrial systems towards products linked to small local production is detected. Thus the local food/beverage has been recognized as a dominant product in high percentage: in Leskovac, even 90.6\%

${ }^{4}$ However, the extent to which this local specificity is dominant in the city of Leskovac has been supported by the fact that a considerable percentage of the respondents (20.4\%) still code traditional food as the city's symbol.

5 For more information about tradition of modenization in Šabac. (See Backović and Spasić, 2016; Backović and Spasić, 2014a; Backović and Spasić 2014b)

$\mathbf{6}$ The term denotes the sense of humor and cheerful spirit of the residents of Šabac, but is also used as a synonym for a rogue or a scoundrel (Stanojević, 2014:195). 
(Leskovac barbecue), Zaječar 76.6\% (Zaječar beer), Užice 72.6\% (komplet lepinja - a sort of flatbread bun), Šabac 39.6\%, Novi Pazar 25.9\% (mantije). The discontinuity in respect of the past and the present product is most evident in Leskovac ${ }^{7}$ and Užice ${ }^{8}$, although all of the examined towns developed as significant industrial centers during the socialist period and faced, due to economic restructuring and privatization processes, drastic decline in employment rates (mostly in industrial sector), particularly in the period 2001-2011 (Petrović, 2014a:65, 110). Therefore, the mentioned shift in the respondents' perception of products that make their city recognizable might also be a positive sign in terms of city branding. However, industrial ethos has still been embedded in the residents' cognitive maps, as respondents in all cities, in one way or another, expect the reactivation of industrial heritage in their city and take the case of Kragujevac in respect of automotive industry ${ }^{9}$ as the most successful strategy of the city recovery.

Table 3

Products by which a city is recognizable

\begin{tabular}{|l|l|}
\hline CITY & PRODUCTS BY WHICH A CITY IS RECOGNIZABLE \\
\hline ŠABAC & $\begin{array}{l}\text { None/I cannot tell }(32.9 \%), \text { traditional food (39.6), factories and industrial } \\
\text { products }(21.7 \%)\end{array}$ \\
\hline SOMBOR & None/I cannot tell (25.3\%), food industry (cheese and dairy) (64.9\%) \\
\hline ZRENJANIN & $\begin{array}{l}\text { None/I cannot tell }(34.5 \%), \text { food industry (oil, margarine, grains, seeds) } \\
(53 \%)\end{array}$ \\
\hline UŽICE & None/I cannot tell (12.8\%), traditional food (72.6\%) \\
\hline KRAGUJEVAC & None/I cannot tell (7.4\%), Fiat (82.3\%) \\
\hline NOVI PAZAR & None/I cannot tell (7.4\%), traditional food (25.9\%), Jeans (62.6\%) \\
\hline ZAJEČAR & None/I cannot tell (16.6\%), traditional beverage (76.6\%) \\
\hline LESKOVAC & None/I cannot tell (4.7\%), traditional food ( $90.6 \%)$ \\
\hline
\end{tabular}

${ }^{7}$ Leskovac possessed a pronounced industrial potential in the past. This is supported by the city's former nickname „Little Manchester“ (http://www.juznasrbija.info/lat/biznis/leskovackako-je-nestao-srpski-mancester.html, $10^{\text {th }}$ March 2017).

8 During the period of socialism, Užice was ranked as a primarily industrial city, but, in the current period, it has completely lost that type of identity.

9 Thanks to the state subsidies provided to „Fiat“, Kragujevac has restructured its car plant and significantly recovered economically since 2008 . 
Table 4

Products by which a city was recognizable

\begin{tabular}{|l|l|}
\hline CITY & PRODUCTS A CITY WAS KNOWN FOR \\
\hline ŠABAC & $\begin{array}{l}\text { None/I cannot tell }(17.4 \%), \text { Zorka factory }(34.1 \%), \text { traditional food and beverage } \\
(21.7 \%)\end{array}$ \\
\hline SOMBOR & None/I cannot tell $(25.3 \%)$, cheese and dairy $(64.9 \%)$ \\
\hline ZRENJANIN & None/I cannot tell (34.5\%), oil, margarine, grains, seeds (53\%) \\
\hline UŽICE & None/I cannot tell $(65.8)$ \\
\hline KRAGUJEVAC & None/I cannot tell (23.2\%), Zastava automobiles (66.7.3\%) \\
\hline NOVI PAZAR & None/I cannot tell (64.8\%), crafts (12.5\%) \\
\hline ZAJEČAR & $\begin{array}{l}\text { None/I cannot tell (14.4\%), factories and industrial products (64.4\%), food industry } \\
(15.7 \%)\end{array}$ \\
\hline LESKOVAC & None/I cannot tell (16.3.7\%), textile (68.4\%) \\
\hline
\end{tabular}

\section{City Pulse}

This CBI dimension represents the most irrational aspect and is rather difficult to measure. We considered it on the basis of the respondents' answers to the question: The city possesses an atmosphere - the soul which makes it especially appealing ${ }^{10}$ on the five-point Likert scale.

Table 5

The city pulls

\begin{tabular}{|l|c|c|c|}
\hline CITY & NUMBER OF RESPONDENTS & MEAN VALUE & STANDARD DEVIATION \\
\hline Užice & 320 & 3.52 & 1.298 \\
\hline Zrenjanin & 302 & 3.60 & 1,022 \\
\hline Zaječar & 313 & 3.63 & 0.907 \\
\hline Novi Pazar & 294 & 3.73 & 1.186 \\
\hline Kragujevac & 373 & 3.77 & 1.287 \\
\hline Leskovac & 301 & 3.79 & 1.100 \\
\hline Šabac & 342 & 3.85 & 1.119 \\
\hline Sombor & 288 & 4.08 & 0.841 \\
\hline
\end{tabular}

10 During the first phase of the field research, the last question was slightly different: Does the city atmosphere („soul of the city“) represent a prerequisite/potential for the development of your city and to what extent?, but we believe that the meaning of the question has not been changed so that we consider it unique in the analysis. The suggested answers to this question on a scale from 1 to 5 were as follows: Strongly agree, Agree, Neither agree or disagree, Disagree, Strongly disagree, with a higher value indicating a strong agreement. 
Among the observed cities, there are statistically significant but slight differences in the assessment of the atmosphere („soul“) of the city (Table 5). In relative terms, the respondents in Sombor and Šabac gave it the highest score and in Užice and Zrenjanin the lowest. Having in mind the dimension of presence, in which Šabac and Sombor were singled out by their specific local features, it came as no surprise that they were also recognized as the cities of "the most powerful" pulse. This refers to Šabac in particular, which was recognized as a festival city as well. In this sense, a higher ranking was expected for the city of Zaječar. The lowest mean value in the case of Zrenjanin might be related to the frequent mentioning of the adverse phenomena by the respondents (economy decline, poor infrastructure, dissolution of factories), which is undoubtedly significant structural limitation in the city rhythm development. The low mean value of the city of Užice could indicate to an insufficiently defined or even lost identity of the industrial city which tries to redefine symbols and searches for new recognizable products in the field of gastronomy.

\section{People}

This last CBI dimension we analyzed is considered on the basis of respondents' answers to the question: „Are there any traits which the residents of this city are known for?"

Table 6

Traits of the residents

\begin{tabular}{|l|l|}
\hline CITY & TRAITS \\
\hline ŠABAC & Cheerful, witty $(29.3 \%)$ \\
\hline SOMBOR & Calm, slow $(21.2)$, friendly $(10.8)$, negative traits (10.4) \\
\hline ZRENJANIN & Negative traits (17.8), slow (15.1), generous, compassionate (12.1) \\
\hline UŽICE & Cheerful, witty $(21.7 \%)$, friendly (12.2\%), competent (10.8\%) \\
\hline KRAGUJEVAC & There are no such traits (36.6.3\%), negative traits (9.4\%), hospitable (9.4\%) \\
\hline NOVI PAZAR & Hospitable (49.8\%), generous and compassionate (14.5\%) \\
\hline ZAJEČAR & Negative traits (26.2\%) \\
\hline LESKOVAC & Negative traits (19.8\%), hospitable (18.7\%) \\
\hline
\end{tabular}

From the city branding perspective, the traits of a city's residents are very important as they reflect the actors' (in)capacity to activate the recognized local potentials. A lack of hospitality, for example, will make it hard to (re)activate the potential identified in the sphere of tourism. On the other hand, the positive traits of the residents will contribute to a positive image of the city in spate of the existing structural development constraints. 
Novi Pazar provides an optimistic image when it comes to the traits of its residents. Hospitality is recognized in a significant percentage (49.8\%) as well as compassion (14.5\%), which might represent a good basis to overcome the structural constraints of the city. Although respondents in Novi Pazar emanate an image of the industrial city in terms of recognizable products, their perception of the residents' traits might be taken as a positive fact for activating the local resources perceived as specific for this city - multiculturalism and gastronomy. On the other hand, Kragujevac as the city with a strong identity potential, reflected in the well profiled city symbols (cultural - historic monuments), and successfully redefined industrial image in the current period, showed the weaknesses with regard to the dimension of 'people'. Namely, the respondents in Kragujevac mostly did not recognize typical traits of their fellow citizens, which might diminish the city image positive promotion.

Similar weakness was observed in Leskovac. Although the hospitality, a trait important to activate the specific local features of Leskovac, such as gastronomy, was recognized as typical by $18.7 \%$ of respondents, the perception of negative traits prevailed (19.8\%). Contrary to Kragujevac, and Leskovac to a certain extent, Užice, a city which suffered the greatest discontinuity in its identity and a city of "the least powerful pulse", showed the upbeat results, similarly as Novi Pazar, regarding the traits of the residents. It appeared as the city of cheerful (21.7\%), friendly $(12.2 \%)$ and competent (10\%) inhabitants.

Šabac and Zaječar, the cities where festivals and nature were recognized as distinguished for the city image, showed divergent results in terms of the people's traits. Whereas Šabac singled out as the city of cheerful and witty people (29.3\%), in Zaječar negative traits (apathy, a lack of agility, etc.) prevailed, which corresponds to the fact that the pulse in this city ranked lower than in Šabac. On the other hand, it is interesting that the residents of Sombor, the city of "the most powerful pulse“, are perceived as predominantly calm and slow (21.2\%). Respondents in Zrenjanin appeared rather consistent in results, as they perceived their city as the biggest transformation loser, frequently emphasized adverse phenomena related to the city and negative traits of the city residents (29,9\%) (apathy, depression, dissatisfaction, slowness).

\section{Conclusion}

Following the Anholt's view that organically developed cities' reputation (strong or weak, positive or negative) should be taken a starting point of a comprehensive social efforts to develop a city brand (Anholt, 2007:15), this paper linked three CBI dimension (presence, pulse, people) to the way residents perceive their cities, which is at the same time considered as a specific (cognitive) soft dimension of territorial capital. The city (re)branding is understood as integral part of complex processes of recognizing local potentials and turning them into development resources (territorial capital). Therefore, the residents' perception is taken as a segment of the city internal culture which might indicate to potentials or obstacles to the city development and branding. 
The presented analysis pointed to at least two aspects of the respondents' perception that have potential for city rebranding of the surveyed cities. Firstly, that refers to other than industrial attributes recognized by respondents as important for the presence of their city, which indicates to the slow emergence of new city identities. These attributes are: gastronomy (Leskovac, Novi Pazar), nature beauties (Sombor), festival atmosphere (Šabac and Zaječar), historic/cultural monuments and cultural institutions (Užice and Novi Pazar). Data gathered by comparison of the products that respondents considered as being typical of the city, both currently and in the past, also confirm the positive shift form city identity linked to large industrial systems towards the one related to locally based production, mostly in the area of gastronomy (Leskovac, Zaječar, Užice, Novi Pazar, Šabac). However, industrial ethos is still firmly embedded in the respondents cognitive maps almost in all of observed cities. Secondly, the cities that have "greater soul" - "stronger pulse" (Šabac i Sombor), and desirable characteristics of people (Novi Pazar, Šabac, Užice) might be taken as cities with greater chance to activate recognized benefits in the process of (re)branding.

Symbolic reading in all eight cities is not consistent, therefore all of them face more or less obstacles regarding the researched dimensions. Thus, even the respondents in Zrenjanin emanated the most negative city image, the majority of respondents in Užice, Kragujevac, Novi Pazar and Leskovac also could not identify any symbol of their city, as one of the elements through which we explored the presence as CBI dimension. Besides Zrenjanin, greater obstacles are also expected in Užice when it comes to the pulse, and in Zaječar when desirable characteristics of people are concerned.

In conclusion, we observed residents' perspective as a very important soft aspect of the territorial capital that should be taken into consideration in the processes of city rebranding and development. The presented findings indicate that significant potential exists in the observed cities. However, the recognition of the importance of the residents' view depends, inter alia, on other soft dimensions of territorial capital (planning culture, institutional sclerosis, etc.) which stayed out of scope of this paper. The research is just a pioneering step towards a further research of city (re)branding and territorial capital as related concepts through sociological surveys, which might significantly contribute to integral territorial development in both academic and policy field.

\section{References}

1. Anholt, S. (2005). Brand New Justice: How Branding Places and Products Can Help the Developing World. Amsterdam: Elsevier Butterworth Heinemann.

2. Anholt, S. (2007). Identity. The New Brand Management for Nations, Cities and Regions. Great Britain: Palgrave Macmillan.

3. Anholt, S. (2008). Place branding: Is it marketing or isn't t? Place Branding and Public Diplomacy, 4 (1): 1-6.

4. Anholt, S. (2010). Places. Identity, Image and Reputation. Great Britain: Palgrave Macmillan. 
5. Anholt, S. (2015). Konkurentni identitet, u: Morgan Najdžel; Pričard Anet i Prajd Rodžer (Ur.). Destinacija kao brend. Beograd: Clio.

6. Ashworth G.; Kavaratzis M. and Warnaby G. (2015). The Need to Rethink Place Branding, in: Kavaratzis Mihalis; Ashworth Gregory and Warnaby Gary (Eds.). Rethinking Place Branding, Comprehensive Brand Development for Cities and Regions. New York - London: Springer.

7. Backović, V. (2005). Evropski gradovi u postsocijalističkoj transformaciji. Sociologija, 47 (1): 27-44.

8. Backović, V. i Spasić, I. (2014a). Vezanost za mesto i lokalni identiteti: studije slučaja četiri grada u Srbiji. Teme, 38 (1): 177-192.

9. Backović, V. i Spasić, I. (2014b). Identitet grada: mišljenje lokalnih aktera u četiri urbane sredine. Sociologija, 56 (2): 101-123.

10. Backović, V. i Spasić, I. (2016). Slika grada između sklada i tenzije: primeri šest gradova u Srbiji. Sociologija, 58 (Posebno izdanje): 210 - 231.

11. Brighetti, A. M. (2010). On Territorology: Towards a General Science of Territory. Theory, Culture \& Society, 27 (1): 52-72.

12. Camagni, R. and Capello, R. (2008). Knowledge-based economy and knowledge creation: the role of space, in: Fratesi Ugo and Senn Lanfranco (Eds.). Growth and innovation of competitive regions: the role of internal and external connections. Berlin: Springer-Verlag.

13. Cox, K. (1997). Introduction: Globalization and Its Politics in Question, in: Cox Kevin (Eds.). Spaces of Globalization: Reasserting the Power of the Local. New York: The Guilford Press.

14. Cvejić, S. (2010). Post-tranziciona Srbija: Izbor ili nužnost, u: Cvejić Slobodan (Ur.). Suživot sa reformama: Građani Srbije pred izazovima „tranzicijskog“ naslecta. Beograd: ISI FF i Čigoja.

15. Devetaković, S. (2012). Teritorijalni kapital i razvojne mogućnosti prostora. Čitalište, 21: 32-40.

16. Dinnie, K. (2011). Introduction to the Theory of City Branding, in: Dinnie Keith (Eds.). City Branding. Theory and Cases. UK: Palgrave Macmillan.

17. Hankinson, G. (2010). Place branding theory: a cross-domain literature review from a marketing perspective, in: Ashwort Gregory and Kavaratzis Mihalis (Eds.). Towards effective Place Brand Management:Branding European Cities and Regions. Cheltenham - Northampton: Edward Elgar Publishing.

18. Hobbsbawm, E. and Ranger, T. (1983). The Invention of Tradition. Cambridge: Cambridge University Press.

19. Horlings, G. L. (2012). Place branding by building coalitions. Place Branding and Public Diplomacy, 8: 295-309.

20. Houghton J. and Stevens A. (2011). City Branding and Stakeholder Engagement, in: Dinnie Keith (Eds.). City Branding, Theory and Cases. New York - London: Palgrave Macmillan.

21. http://www.juznasrbija.info/lat/biznis/leskovac-kako-je-nestao-srpski-mancester.html. Pregledano 10. 03. 2017.

22. Jayne, M. (2006). City and Consumption. London \& New York: Routledge.

23. Kavaratzis, M. and Ashworth, G. (2010). Place branding: where do we stand?, in: Ashworth Gregory and Kavaratzis Mihalis (Eds.). Towards Effective Place Brand Management, Branding European Cities and Regions, Cheltenham - Northampton: Edward Elgar Publishing. 
24. Kotler, P.; Asplund, C.; Rein, I.; Haider, D. (1999). Marketing Places Europe: How to Attract Investments, Industries, Residents and Visitors to Cities, Communities, Regions and Nations in Europe. UK: Financial Times.

25. Lazarević-Bajec, N. (2009). Lokalno strateško planiranje u Srbiji: evaluacija rezultata, Regionalni razvoj, prostorno planiranje i strateško upravljanje. Beograd: Institut za arhitekturu i urbanizam Srbije.

26. Lazić, M. (2011). Čekajući kapitalizam:nastanak novih klasnih odnosa u Srbiji. Beograd: Službeni glasnik.

27. Luković, D. (2013). Brendiranje gradova i regiona: teorijske osnove $i$ prakse u Istočnoj i Zapadnoj Evropi. Beograd: Univerzitet u Beogradu, Fakultet političkih nauka.

28. Lury, C. (2004). Brands. The logos of the global economy. London \& New York: Routledge.

29. Miles, S. and Milles, M. (2004). Consuming Cities. Basingstoke: Palgrave.

30. Molnar, D. (2013). Činjenice o regionalnim razlikama u Srbiji, Kvartalni monitor ekonomskih trendova i politika u Srbiji. Beograd: Fondacija za razvoj ekonomske nauke (FREN), Ekonomski fakultet UB.

31. Petovar, K. (2003). Naši gradovi između države i građanina. Beograd: Geografski fakultet, Arhitektonski fakultet, Institut za arhitekturu i urbanizam.

32. Petrović, M. (2009). Transformacija gradova:ka depolitizaciji urbanog pitanja. Beograd: Čigoja štampa, ISI FF.

33. Petrović, M. (2014). Pojam teritorijalnog kapitala kao okosnica istraživanja lokalnog-urbanog razvoja, u: Petrović Mina (Ur.). Strukturni i delatni potencijal lokalnog razvoja. Beograd: ISI FF i Sociološko udruženje Srbije i Crne Gore.

34. Petrović, M. (2014a). Društvo i gradovi: između lokalnog i globalnog. Beograd: Čigoja štampa, Institut za sociološka istraživanja, FFUB.

35. Petrović M. i Toković M. (2016). Neoendogeni razvoj i ekološki paradoks:studija slučaja šest gradova. Sociologija, 58 (Posebno izdanje): 181-209.

36. Ritzer, G. (2001). Explorations in the Sociology of Consumption: Fast Food, Credit Cards and Casinos. US: Sage Publications.

37. Stanojević, M. (2014). Potencijali lokanog razvoja gradova: kreativna upotreba lokalne tradicije, u: Petrović Mina (Ur.). Strukturni i delatni potencijal lokalnog razvoja. Beograd: ISI FF i Sociološko udruženje Srbije i Crne Gore.

38. Storper, M. (1997). The Regional World. New York: Guilford.

39. Švob-Đokić, N. (Ur.). (2007). Cultural Transitions in Southeastern Europe. The creative city: Crossing visions and new realities in the region. Zagreb: Institute for International Relations.

40. Vasiljević, A. (2009). Kreiranje identiteta - brendiranje grada. Časopis Kultura, 122/123: 104-119.

41. Vujošević, M. (2014). Kriza strateškog istraživanja, mišljenja i upravljanja u Srbiji: otvorena pitanja upravljanja teritorijalnim kapitalom na lokalnom i regionalnom nivou. Kako je Beograd potčinio periferiju Srbije?, u: Petrović Mina (Ur.). Strukturni i delatni potencijal lokalnog razvoja. Beograd: ISI FF i Sociološko udruženje Srbije i Crne Gore.

42. Vujošević, M.; Zeković, S. i Maričić, T. (2010). Postsocijalistička tranzicija u Srbiji i teritorijalni kapital Srbije. Stanje, neki budući izgledi i predvidljivi scenariji. Beograd: Institut za arhitekturu i urbanizam Srbije. 
43. Vujović, S. (2014). Socioprostorni identitet Beograda u kontekstu urbanog i regionalnog razvoja Srbije. Sociologija, 56 (2): 145-166.

44. Zukin, S. (1995). The culture of Cities. Cambridge, Massachusetts/Oxford: Blackwell.

45. Zukin, S. (1996). Postmodern Urban Landscapes: Mapping Culture and Power, in: Harloe Michael (Eds.). The Sociology of Urban Communities III. Chelthenham: E. Elgar. 
Pregledni rad

Milena Toković

Sveučilište u Beogradu, Filozofski fakultet, Srbija

e-mail:mstanojevic85@gmail.com

Mina Petrović

Sveučilište u Beogradu, Filozofski fakultet, Srbija

e-mail:mipetrov@f.bg.ac.rs

\section{Potencijal "mekih" faktora teritorijalnog kapitala u procesu brendiranja: istraživanje osam gradova srednje veličine u Srbiji}

\section{Sažetak}

Cilj rada ispitivanje je potencijala za brendiranje „mekih“ činilaca teritorijalnog kapitala u gradovima srednje veličine u Srbiji. Koncept teritorijalnog kapitala odnosi se na ukupni potencijal gradskog razvoja koji kombinira objektivne, „tvrde“ i subjektivne, „meke“ činioce kako bi privukao investicije i ostvario lokalni razvoj određenog područja. Budući da je brendiranje gradova postalo imperativ lokalnih razvojnih strategija, rad ima za cilj povezati te koncepte kako bi se naglasio mogući potencijal za brendiranje mekih dimenzija teritorijalnog kapitala. U radu su korišteni podaci istraživanja provedenog u periodu od 2013. do 2015. godine u okviru Instituta za sociološka istraživanja Filozofskog fakulteta Univerziteta u Beogradu, na reprezentativnom uzorku stanovništva od 18 do 65 godina u osam gradova. U prvom dijelu teksta raspravlja se o konceptu teritorijalnog kapitala, koji se dovodi u vezu s procesom brendiranja grada. U drugom dijelu teksta analizira se društvo Srbije. Najprije se sumiraju glavne karakteristike društveno-prostorne transformacije u postsocijalističkom periodu i ukazuje se na neusklađenost između teritorijalnog kapitala i procesa brendiranja gradova. Dalje je predstavljena metoda istraživanja, koja se fokusira na percepciju ispitanika/građana, zapostavljenu meku dimenziju teritorijalnog kapitala. Vodeći se perspektivom brendiranja gradova kao postavljenim analitičkim ciljem, u tumačenju dobivenih rezultata primijenjene su prilagođene dimenzije modela CBI (prepoznatljivost, puls, ljudi). Rezultati istraživanja tumačeni su iz perspektive korištenih koncepata u radu. U zaključku se u kratkim crtama sumira zašto i na koji se način promatrane meke dimenzije teritorijalnog kapitala mogu prepoznati kao relevantan potencijal u procesu (re)brendiranja istraživanih gradova.

Ključne riječi: brendiranje gradova, teritorijalni kapital, „meki“ činioci teritorijalnog kapitala, Srbija. 